\title{
Effect of Linseed Oil Supplementation on Ruminal Digestion in Dairy Cows Fed Diets with Different Forage:Concentrate Ratios
}

\author{
K. Ueda ${ }^{1}$, A. Ferlay, J. Chabrot, J. J. Loor, ${ }^{2}$ Y. Chilliard, and M. Doreau \\ Unité de Recherches sur les Herbivores, \\ Institut National de la Recherche Agronomique, Theix, 63122 \\ Saint-Genès-Champanelle, France.
}

\begin{abstract}
The effect of linseed oil (LSO) supplementation on total-tract and ruminal nutrient digestibility, $\mathrm{N}$ metabolism, and ruminal fluid characteristics was investigated in dairy cows fed diets containing different forage to concentrate ratios $(\mathrm{F}: \mathrm{C})$. The experimental design was a $4 \times 4$ Latin square with $2 \times 2$ factorial arrangement of treatments. Four lactating Holstein cows were fed a forage-rich diet without LSO (F; F:C $=65: 35$, dry matter basis), a forage-rich diet with LSO (FO; F:C = 65:32, 3\% LSO), a concentrate-rich diet without LSO $(\mathrm{C} ; \mathrm{F}: \mathrm{C}=35: 65)$, or a concentrate-rich diet with LSO (CO; F:C $=35: 62,3 \%$ LSO). Total-tract digestibility of $\mathrm{DM}$ and OM was greater with supplemental LSO. A tendency for greater total-tract digestibility of NDF and $\mathrm{ADF}$ also was observed in cows fed LSO. Ruminal digestibility of $\mathrm{NDF}$ or $\mathrm{ADF}$ decreased when $\mathrm{CO}$ was fed compared with $\mathrm{C}$. In contrast, feeding FO increased NDF or ADF digestibility compared with F. Although ruminal starch digestion was nearly complete with all diets, digestibility was greater when cows were fed C or $\mathrm{CO}$ compared with $\mathrm{F}$ or FO. Bacterial $\mathrm{N}$ flow to the duodenum decreased when FO was fed compared with F. In contrast, feeding CO increased bacterial-N flow compared with C. Neither F:C nor LSO supplementation affected ruminal $\mathrm{pH}$ or total VFA concentration in ruminal fluid. However, molar proportion of propionate was greater with $\mathrm{C}$ or $\mathrm{CO}$ compared with $\mathrm{F}$ or $\mathrm{FO}$ and increased with LSO supplementation regardless of F:C. Molar proportion of $n$-butyrate decreased with LSO supplementation. Total protozoal numbers in ruminal fluid decreased markedly only when $\mathrm{CO}$ was fed. Overall, data show that feeding LSO had no negative effects
\end{abstract}

Received March 18, 2003.

Accepted July 31, 2003.

Corresponding author: M. Doreau; e-mail: doreau@clermont. inra.fr.

${ }^{1}$ Present address: Graduate School of Agriculture, Hokkaido University, Sapporo, 060-8589, Japan; e-mail: ueko@anim.agr.hokudai. ac.jp.

${ }^{2}$ Present address: Department of Animal Sciences, University of Illinois, Urbana 61801; e-mail: jloor@uiuc.edu. on total-tract digestion in dairy cows but may decrease ruminal fiber digestibility when fed with high-concentrate diets. The widely spread idea that LSO decreases digestibility, arising from studies with sheep, did not seem to apply to lactating cows fed 3\% LSO.

(Key words: dairy cow, forage to concentrate ratio, linseed oil, ruminal digestion)

Abbreviation key: $\mathbf{C}=$ concentrate-rich diet without LSO, CLA = conjugated linoleic acid, $\mathbf{C O}=$ concentraterich diet with $3 \%$ LSO, $\mathbf{F}=$ forage-rich diet without LSO, FO = forage-rich diet with $3 \% \mathrm{LSO}, \mathbf{F}: \mathbf{C}=$ forage to concentrate ratio, $\mathbf{L A B}=$ liquid associated bacteria, LSO = linseed oil, $\mathbf{P P B}=$ purine and pyrimidine bases, SAB $=$ solid-adherent bacteria .

\section{INTRODUCTION}

Recently, there has been interest in enhancing the concentration of the cis9,trans 11 - isomer of conjugated linoleic acid (CLA) in bovine milk fat due to its potential as a protective agent against cancer and cardiovascular disease (Roche et al., 2001). The $n$-3 fatty acids also have been associated with positive effects on human health for a long time. Due to their high linoleic and linolenic acid content, feeding fresh grass or vegetable oils to dairy cows increased cis9,trans11-CLA and $n-3$ fatty acid concentration in milk (Demeyer and Doreau, 1999; Chilliard et al., 2001). Linseed oil (LSO) contains high concentrations of linolenic acid (ca. $50 \%$ of total fatty acids), and feeding LSO to lactating cows increased CLA and $n-3$ fatty acid content in milk fat substantially compared with an unsupplemented diet (Dhiman et al., 2000).

It is well recognized that feeding vegetable oils containing unsaturated fatty acids has the potential to inhibit ruminal fermentation (Jenkins, 1993). Supplementation with LSO in particular severely decreased ruminal digestion in sheep, accompanied with a considerable decrease in ruminal protozoal counts (Ikwuegbu and Sutton, 1982; Sutton et al., 1983; Broudiscou et al., 1994). There is little information regarding LSO supplementation and digestion in lactating dairy cows and none, to our knowledge, at levels (2 to $3 \%$ of DM) 
that would be of practical significance. A decrease in ruminal digestion of nutrients would be an important factor limiting the amount of LSO that can be added to dairy diets.

Doreau et al. (1991) found no effect of $10 \%$ rapeseed oil supplementation on ruminal OM degradation when dairy cows were fed a basal diet with $50 \%$ fescue hay. However, rapeseed oil decreased carbohydrate digestibility in the total tract when fed with corn silage compared with natural grassland hay (Ben Salem et al., 1993). These results indicated that the effects of unsaturated fatty acid on ruminal digestion could be variable due to composition of the basal diet.

Palmquist (1988) hypothesized that the negative effect of unsaturated fatty acids on ruminal digestion would be minimized if the diet contained a high proportion of forage due to the ability of forage to promote normal rumen function for maximum biohydrogenation. Bateman and Jenkins (1998) provided evidence that large amounts of soybean oil in combination with high-forage diets could be fed without depressing nutrient digestibility in the total tract. Although hydrogenation of linoleic and linolenic acid in the rumen were reported to average 85 and $90 \%$, the extent of ruminal hydrogenation may sometimes decrease with consumption of concentrate-rich diets (Doreau and Ferlay, 1994). Under these circumstances, the increase in ruminal availability of linolenic acid may impose an additional burden on normal ruminal digestion. However, it is uncertain if LSO would have an effect on ruminal digestion in dairy diets containing varying amounts of concentrate.

The objective of this study was to determine the effect of LSO supplementation on ruminal digestion in dairy cows when diets with different forage to concentrate ratios (F:C) are fed. Data on duodenal fatty acid flows and fatty acid digestibility (Loor et al., 2002b), and production responses and milk fatty acid profiles (Loor et al., 2002a) are presented elsewhere.

\section{MATERIALS AND METHODS}

\section{Animals, Experimental Design, and Dietary Treatments}

Four multiparous Holstein cows with cannulas in the rumen (made of polyvinyl chloride and polyamide, i.d. $120 \mathrm{~mm}$ ) and proximal duodenum (made of plastisol, T-shaped with a gutter-type base) were used. Surgery was performed aseptically at least $1 \mathrm{yr}$ before the experiment under general anesthesia using halothane (ICI Pharma, Paris, France). Average BW and DIM for cows at the beginning of the experiment was $658 \pm 13 \mathrm{~kg}$ and $71 \pm 16 \mathrm{~d}$. Milk yield and DMI during the study averaged $26.7 \pm 2.6$ and $20.2 \pm 1.0 \mathrm{~kg} / \mathrm{d}$ and were not affected by F:C or LSO. The experiment was conducted as a $4 \times 4$ Latin square with a $2 \times 2$ factorial arrangement of treatments. Prior to the first experimental period, a diet with intermediate levels of F:C and LSO (F:C $=50: 48.5,1.5 \%$ LSO on DM basis) was fed for 3 wk. Each experimental period within the Latin square lasted $5 \mathrm{wk}$. Treatments were a forage-rich diet without LSO (F; F:C = 65:35 DM basis), a forage-rich diet with LSO (FO; F:C = 65:32, 3\% LSO), a concentrate-rich diet without LSO (C; F:C = 35:65), or a concentrate-rich diet with LSO (CO; F:C = 35:62, 3\% LSO). Diets were formulated according to Institut National de la Recherche Agronomique guidelines (INRA, 1989). Cows were housed in a tie-stall barn throughout the experiment. Ingredients and chemical composition of the diets are shown in Table 1. Hay was made from a first cut of mainly grasses derived from semimountain natural grassland, and was given without chopping as the sole forage. Feeds were offered in 3 equal portions at 0900 , 1330, and 1700 h. Hay and concentrates were given separately. Cows had ad libitum access to the diets. The desired F:C ratio was maintained by daily adjustment of offered amounts of forages and concentrates, depending on the composition of refusals of the previous day. The LSO was evenly mixed with the concentrate. The last 2 wk of each period were used for sample collection. All experimental procedures were conducted in accordance with French guidelines concerning the use of experimental animals and animal welfare (Anonymous, 1988).

\section{Measurements and Analyses}

To determine total-tract digestibility, a total fecal collection was performed during $6 \mathrm{~d}$ in wk 4 . A $1 \%$ representative sample from recovered feces was taken every morning, and DM content measured at $103^{\circ} \mathrm{C}$ for $24 \mathrm{~h}$. This value was used to estimate daily fecal DM excretion. Another aliquot (0.5\% of collected feces) also was sampled and pooled across days. Pooled fecal samples were stored at $-20^{\circ} \mathrm{C}$ before lyophilization (Thermovac TM-20, Froilabo, Ozoir-la-Ferrière, France). Samples for each feedstuff (hay, concentrate mixture, soybean meal) were collected during the same $6 \mathrm{~d}$ as for feces, and a composite sample was made. Composite feed samples and lyophilized feces were ground through a 1-mm screen (Christy and Norris Ltd., Chelmsford, England), and analyzed for OM, N, NDF, ADF, starch, and total fatty acids. Organic matter content was determined by ashing at $550^{\circ} \mathrm{C}$ for $6 \mathrm{~h}$. Nitrogen was analyzed by the Kjeldahl procedure (AOAC, 1990). Contents of NDF and ADF were analyzed by the detergent method after pretreatment with amylase (Van Soest et al., 1991). Starch was analyzed according to Faisant et 
Table 1. Ingredient and chemical composition of the experimental diets.

\begin{tabular}{|c|c|c|c|c|}
\hline \multirow[b]{2}{*}{ Item } & \multicolumn{4}{|c|}{$\operatorname{Diet}^{1}$} \\
\hline & $\mathrm{F}$ & $\mathrm{FO}$ & $\mathrm{C}$ & $\mathrm{CO}$ \\
\hline \multicolumn{5}{|l|}{ Ingredient, $\%$ of DM } \\
\hline Grass hay, long cut & 65.0 & 65.0 & 35.0 & 35.0 \\
\hline Soybean meal, $44 \% \mathrm{CP}$ & 7.0 & 17.0 & 0 & 5.0 \\
\hline Linseed oil ${ }^{2}$ & 0 & 3.0 & 0 & 3.0 \\
\hline \multicolumn{5}{|l|}{ Concentrate mixture } \\
\hline Ground wheat & 14.0 & 7.5 & 32.4 & 28.4 \\
\hline Rapeseed meal & 5.0 & 2.6 & 11.6 & 10.2 \\
\hline Sunflower meal & 4.1 & 2.2 & 9.7 & 8.6 \\
\hline Wheat bran & 2.8 & 1.5 & 6.5 & 5.7 \\
\hline Distiller's bran & 0.6 & 0.3 & 1.3 & 1.1 \\
\hline Wet beet molasses & 0.6 & 0.3 & 1.3 & 1.1 \\
\hline Limestone & 0.7 & 0.4 & 1.6 & 1.3 \\
\hline Sodium chloride & 0.1 & 0.1 & 0.3 & 0.3 \\
\hline Mineral-vitamin $\operatorname{mix}^{3}$ & 0.1 & 0.1 & 0.3 & 0.3 \\
\hline \multicolumn{5}{|c|}{ Chemical composition, \% of DM } \\
\hline $\mathrm{OM}$ & 91.5 & 91.7 & 92.3 & 92.5 \\
\hline $\mathrm{CP}$ & 16.9 & 19.1 & 17.4 & 18.2 \\
\hline NDF & 44.5 & 43.3 & 33.7 & 32.8 \\
\hline $\mathrm{ADF}$ & 24.7 & 24.1 & 18.3 & 17.9 \\
\hline Starch & 10.2 & 5.7 & 23.4 & 20.6 \\
\hline Total fatty acids & 1.6 & 4.7 & 1.9 & 5.1 \\
\hline
\end{tabular}

al. (1995). Total fatty acid content of hay, concentrate mixture, and soybean meal was determined individually by GLC (CP-3800, Varian, Les Ulis, France) after a direct acidic methylation procedure described elsewhere (Loor et al., 2002b).

Flows of nutrients to the duodenum in wk 4 were assessed using the double marker method of Faichney (1980), with $\mathrm{YbCl}_{3}$ and polyethylene glycol. Marker solutions (400 mg of $\mathrm{Yb} / \mathrm{L}, 65 \mathrm{~g}$ of polyethylene glycol/L) were continuously infused into the rumen at a rate of $100 \mathrm{~mL} / \mathrm{h}$ through individual tubes that passed through the rumen cannula and into the rumen. In order to equilibrate ruminal marker concentrations, marker infusion began at $1000 \mathrm{~h}$ on $\mathrm{d} 1$ of wk 4 . Duodenal samples were collected at 0930,1230,1530,1830, 2130, and $2300 \mathrm{~h}$ on d $3 ; 0030,0200,0330,0500,0630,1700$, and $2000 \mathrm{~h}$ on $\mathrm{d} 4$; and 0800,1100 , and $1400 \mathrm{~h}$ on $\mathrm{d} 5$. A $100-\mathrm{mL}$ aliquot of duodenal digesta was squeezed through a nylon mesh ( $250 \mu \mathrm{m}$ pore size) immediately after each sampling. Filtrate and residue were independently pooled across sampling time and stored at $-20^{\circ} \mathrm{C}$. A second $100-\mathrm{mL}$ aliquot, representing total duodenal digesta, also was collected, pooled across time, and stored prior to analysis. A portion of fresh duodenal sample (total, filtrate, residue) was analyzed for DM, $\mathrm{OM}$, and $\mathrm{N}$ by methods mentioned previously. Ammonia $\mathrm{N}$ was measured by an automated colorimetric technique using Berthelot's reaction, and polyethylene gly- col was measured by an improved turbidimetric method (Malawer and Powell, 1967) using a spectrophotometer (UV-120, Shimadzu, Kyoto, Japan). The remaining portion of duodenal samples was lyophilized and ground as mentioned previously. Lyophilized samples were used to measure NDF, ADF, starch, $\mathrm{Yb}$ (by atomic absorption spectrophotometry at $398.8 \mathrm{~nm}$ with an acetylene $/ \mathrm{N}_{2} \mathrm{O}$ mixture flame; 2380 spectrophotometer, Perkin Elmer, Bois d'Arcy, France), and purine and pyrimidine bases (PPB) with HPLC (Lassalas et al., 1993; Alliance HPLC system, Waters, Milford, MA). The sum of PPB concentration (cytosine, uracile, guanine, thymine, adenine) was used as reference for nucleic acid content.

A representative sample of ruminal contents (900 g) was taken by hand at 0900,1130 , and $1400 \mathrm{~h}$ on $\mathrm{d} 1$ or 3 in wk 4 and immediately squeezed through a 250 $\mu \mathrm{m}$ mesh nylon cloth. Residue and filtrate were quickly transported to the laboratory for isolation of bacteria. Liquid-associated bacteria (LAB) were extracted from filtrate by successive centrifugations at $800 \times g$ for 15 min, followed by a final centrifugation at $27,000 \times g$ for $30 \mathrm{~min}$ at $4^{\circ} \mathrm{C}$. Solid-adherent bacteria (SAB) were recovered from the residue. The $\mathrm{LAB}$ and $\mathrm{SAB}$ were recovered according to Legay-Carmier and Bauchart (1989). The washed bacterial pellets were lyophilized, ground with mortar and pestle, and then analyzed for $\mathrm{OM}, \mathrm{N}$, and PPB. Concentration of PPB also was mea- 
sured in the residue remaining after $\mathrm{SAB}$ isolation. Because the recovered $\mathrm{SAB}$ was to be a part of total $\mathrm{SAB}$, the remaining amount was estimated using $\mathrm{PPB}$ concentrations in the recovered $\mathrm{SAB}$ and in the residue. Content of LAB and SAB was expressed as bacterial N in fresh rumen digesta.

Concentration of $\mathrm{Yb}$ and polyethylene glycol in total, filtrate, and residue was used to calculate a reconstitution factor to estimate true duodenal DM flows (Faichney, 1980), and flows of OM, N, NDF, ADF, starch, and nonammonia $\mathrm{N}$. The reconstitution factor also was used to partition total duodenal DM flows between filtrate and residue DM flows. Duodenal bacterial OM and N flows were calculated according to the following equation, assuming that the composition of bacteria flowing into duodenum in the filtrate and residue corresponded to that of ruminal LAB and SAB: Bacterial OM or $\mathrm{N}$ flow $=$

$$
\begin{aligned}
& \text { Filtrate PPB flow } \times \frac{[\mathrm{OM} \text { or } \mathrm{N}]_{\mathrm{LAB}}}{[\mathrm{PPB}]_{\mathrm{LAB}}}+ \\
& \text { Residue PPB flow } \times \frac{[\mathrm{OM} \text { or }]_{\mathrm{SAB}}}{[\mathrm{PPB}]_{\mathrm{SAB}}}
\end{aligned}
$$

where $[\mathrm{PPB}]_{\text {filtrate, residue, } \mathrm{LAB}, \mathrm{SAB}}=\mathrm{PPB}$ content in duodenal filtrate, residue, $\mathrm{LAB}$, and $\mathrm{SAB}$ on $\mathrm{DM}$ basis, and $[\mathrm{OM} \text { or } \mathrm{N}]_{\mathrm{LAB}, \mathrm{SAB}}=\mathrm{OM}$ or $\mathrm{N}$ content in $\mathrm{LAB}$ and $\mathrm{SAB}$ on DM basis. True ruminal OM digested was calculated by difference between duodenal OM flow and bacterial OM flow.

Ruminal fluid ( $100 \mathrm{~mL}$ ) was collected from the ventral sac by suction via a polyethylene tube at 0900 and 1130 $\mathrm{h}$ on $\mathrm{d} 2$ and 4 in wk 4 . The $\mathrm{pH}$ was measured immediately after collection. Subsamples of ruminal fluid were stored in 3 separate tubes with a mixture of $50 \%$ glycerol and $1 \%$ glutaraldehyde in water $(1: 9 \mathrm{vol} / \mathrm{vol}$ of rumen fluid) at $4^{\circ} \mathrm{C}, 5 \%$ o-phosphoric acid (1:9 vol/vol of rumen fluid) at $-20^{\circ} \mathrm{C}$, and $20 \% \mathrm{NaCl}(9: 1 \mathrm{vol} / \mathrm{vol}$ of rumen fluid) at $-20^{\circ} \mathrm{C}$, to estimate protozoal counts, VFA concentration, and ammonia $\mathrm{N}$ concentration, respectively. Protozoa were counted in a Dollfuss cell (Maillière, Aubière, France). Concentrations of VFA were determined by GLC (GC8100, Carlo Erba Instruments, Italy) using iso-caproate as an internal standard according to Jouany (1982). Ammonia N was determined as above mentioned.

Ruminal in situ degradation of hay DM was estimated during wk 5 . Nylon bags ( $46 \mu \mathrm{m}$ pore size; Ankom, Fairport, NY) contained $3 \mathrm{~g}$ of hay ground through a $0.8-\mathrm{mm}$ screen. Eighteen bags (3/sampling time) were placed in the rumen at $0900 \mathrm{~h}$ and removed after 3, 6, $12,24,48$, and $72 \mathrm{~h}$ of incubation. Disappearance of
$\mathrm{DM}$ at each incubation time was determined from the amount of residue $\mathrm{DM}\left(80^{\circ} \mathrm{C}\right.$ for $\left.48 \mathrm{~h}\right)$ in bags. To estimate degradation kinetic parameters, disappearance data were fitted to the following exponential:

$$
\mathrm{D}(\mathrm{t})=\mathrm{a}+\mathrm{b}\left(1-\mathrm{e}^{-\mathrm{ct}}\right)
$$

where $\mathrm{D}(\mathrm{t})=$ proportion of hay degraded at time $\mathrm{t}$, a $=$ rapidly degradable fraction, $\mathrm{b}=$ slowly degradable fraction, and $c=$ degradation rate of $b$. Nonlinear fitting was performed with the NLIN procedure of SAS (SAS Inst., Inc., Cary, NC). Theoretical degradability (TD) was calculated using the following formula:

$$
\mathrm{TD}=\mathrm{a}+\mathrm{b} \times \mathrm{c} /(\mathrm{c}+\mathrm{k})
$$

where $\mathrm{k}=$ particle passage rate from the rumen. Calculations were made with a common value of $\mathrm{k}$ for all diets $(4 \% / \mathrm{h})$. In this case, TD represents the potential degradability depending on microbial activity alone.

All data were analyzed as a $4 \times 4$ Latin square using the MIXED procedure of SAS (SAS Inst., Inc.). The statistical model included cow as random effect, and period, LSO supplementation, $\mathrm{F}: \mathrm{C}$, and $\mathrm{LSO} \times \mathrm{F}: \mathrm{C}$ as fixed effects. For the statistical analysis of ruminal fluid characteristics ( $\mathrm{pH}, \mathrm{VFA}$, and protozoa), sampling time and sampling time $\times$ treatment were added to the model and analyzed using repeated measures. Main effects (F:C and LSO supplementation) were considered to be significant when $P \leq 0.05$. Interactions between $\mathrm{F}: \mathrm{C}$ and LSO supplementation were considered to be significant when $P \leq 0.10$.

\section{RESULTS AND DISCUSSION}

\section{Ruminal and Total-Tract Digestibility of Nutrients}

There was no difference $(P>0.05)$ in daily DM or OM intake between treatments (Table 2). Daily DMI was not affected $(P>0.05)$ by LSO supplementation, in agreement with recent reports pertaining to lactating dairy cows (Dhiman et al., 2000) or goats (Chilliard et al., 2002) fed LSO at 4 to $6 \%$ of diet DM.

There was an interaction $(P<0.10)$ between $\mathrm{F}$ : $\mathrm{C}$ and LSO supplementation for NDF digestibility. Ruminal NDF digestibility increased with LSO supplementation to the forage-rich diet, whereas it decreased with supplementation to the concentrate-rich diet. Ruminal ADF digestibility followed the same trend $(P=0.10)$ as ruminal NDF digestibility. Reports evaluating effects of LSO supplementation on ruminal digestibility are limited to sheep receiving diets containing 67\% (Ikwuegbu and Sutton, 1982; Sutton et al., 1983) or $45 \%$ concentrate (Broudiscou et al., 1994). Overall, they ob- 
Table 2. Intake and digestion of DM, OM, fiber, and starch by cows fed diets containing a high proportion of forage without (F) or with linseed oil (FO), and a high proportion of concentrate without (C) or with linseed oil (CO).

\begin{tabular}{|c|c|c|c|c|c|c|c|c|}
\hline \multirow[b]{2}{*}{ Variable } & \multicolumn{4}{|c|}{ Diet } & \multirow[b]{2}{*}{ SEM } & \multicolumn{3}{|c|}{ Effect $(P=)$} \\
\hline & $\mathrm{F}$ & $\mathrm{FO}$ & $\mathrm{C}$ & $\mathrm{CO}$ & & $\mathrm{F}: \mathrm{C}$ & Oil & Int $^{1}$ \\
\hline DM intake, $\mathrm{kg} / \mathrm{d}$ & 20.4 & 19.6 & 20.5 & 20.4 & 1.0 & 0.61 & 0.59 & 0.69 \\
\hline \multicolumn{9}{|l|}{ Ruminal digestibility, $\%$ of intake } \\
\hline Apparent OM & 36.3 & 43.4 & 41.9 & 35.4 & 3.5 & 0.76 & 0.93 & 0.11 \\
\hline True OM & 57.2 & 60.8 & 61.8 & 57.2 & 3.0 & 0.87 & 0.87 & 0.23 \\
\hline $\mathrm{NDF}$ & 42.7 & 58.2 & 44.3 & 34.2 & 6.2 & 0.13 & 0.68 & 0.09 \\
\hline $\mathrm{ADF}$ & 39.0 & 57.2 & 35.5 & 24.6 & 7.3 & 0.06 & 0.64 & 0.10 \\
\hline Starch & 89.0 & 85.9 & 91.5 & 94.2 & 1.0 & $<0.01$ & 0.82 & 0.03 \\
\hline \multicolumn{9}{|l|}{ Total-tract digestibility, $\%$ of intake } \\
\hline $\mathrm{DM}$ & 66.8 & 68.2 & 68.4 & 71.7 & 0.6 & $<0.01$ & $<0.01$ & 0.15 \\
\hline $\mathrm{OM}$ & 68.5 & 70.0 & 70.0 & 73.3 & 0.6 & $<0.01$ & $<0.01$ & 0.12 \\
\hline $\mathrm{NDF}$ & 61.4 & 63.3 & 51.0 & 54.0 & 1.6 & $<0.01$ & 0.07 & 0.66 \\
\hline $\mathrm{ADF}$ & 59.0 & 61.7 & 43.2 & 47.2 & 1.9 & $<0.01$ & 0.06 & 0.68 \\
\hline Starch & 98.0 & 97.4 & 98.6 & 98.9 & 0.2 & $<0.01$ & 0.17 & 0.03 \\
\hline
\end{tabular}

${ }^{1}$ Int = interaction between F:C and oil.

served that LSO supplementation decreased ruminal digestibility of $\mathrm{OM}$ and fiber with the decrease being more pronounced for the fiber fraction. In the present experiment, a decrease in ruminal digestibility of $\mathrm{OM}$ (15.5\% units), true $\mathrm{OM}(7.4 \%), \mathrm{NDF}(22.7 \%)$, and $\mathrm{ADF}$ (30.7\%) was found with LSO supplementation to the concentrate-rich diet. The greater decrease in fiber digestion was consistent with previous reports. In contrast to results from other studies and those observed with the concentrate-rich diet, ruminal $\mathrm{OM}$ and fiber digestibility increased markedly with LSO supplementation to the forage-rich diet. Such an effect of lipids is uncommon, but a positive effect on $\mathrm{OM}$ and fiber digestion also was observed previously when fish oil (1.5 to $2.3 \%$ of $\mathrm{DM}$ ) was added to dairy diets (Doreau and Chilliard, 1997) or when linseed (11\% of DM) was fed to sheep (Wachira et al., 2000). In the present study, however, the amount of soybean meal in $\mathrm{FO}$ was greater compared with other diets (Table 1). Despite the fact that theoretical requirements for degradable protein (INRA, 1989) were met with all diets, greater supply of rumen degradable protein from soybean meal with FO may have enhanced ruminal microbial activity, resulting in increased ruminal fiber digestibility.

Dietary F:C seems important in modulating the response to LSO supplementation on ruminal digestibility, as suggested by Palmquist (1988), for different lipid sources. In previous studies reporting strong negative effects on ruminal fiber digestibility with LSO supplementation (Ikwuegbu and Sutton, 1982; Sutton et al., $1983)$, the proportion of concentrate (67\% in DM basis) was as high as that in the concentrate-rich diet fed in the current experiment. In studies showing a positive effect of $n-3$ fatty acids, fish oil with a corn silage-based diet (Doreau and Chilliard, 1997), or linseed with a dried grass-based diet (Wachira et al., 2000), on ruminal fiber digestibility, the proportion of dietary concentrate was similar (30 to 35\%) to that of the forage-rich diets in the present experiment. Available data based on indirect comparisons of the effects of lipid supplementation to different diets suggest that the effect of LSO supplementation on ruminal fiber digestion may often become negative when diets contain a high proportion of concentrate and/or starch. For example, supplementation with rapeseed oil (Doreau et al., 1991) at $10 \%$ of DM to hay-based diets (50\%) had no effect on ruminal OM and fiber digestion. When canola seed was added ( $10 \%$ of $\mathrm{DM})$ to steer diets with different fiber content, however, there was no negative effect on ruminal OM or fiber digestibility (Hussein et al., 1995).

Total-tract $\mathrm{DM}$ and $\mathrm{OM}$ digestibility were greater $(P$ $<0.01$ ) in cows fed increasing amounts of concentrate (Table 2). Total-tract NDF and ADF digestibility, however, was lower in response to feeding the high-concentrate diet. Supplementation with LSO caused modest but significant increases $(P<0.01)$ in total-tract DM and $\mathrm{OM}$ digestibility, and a tendency for increased NDF and $\mathrm{ADF}$ digestibility. Literature data on the interaction between basal diet and lipid supplementation for total-tract digestibility are inconsistent. A negative effect of $7 \%$ rapeseed oil on digestion was observed in a diet based on corn silage, whereas differences were not significant with a hay-based diet (Ben Salem et al., 1993). In contrast, Cottyn et al. (1971) showed that total-tract $\mathrm{CF}$ digestibility in sheep was decreased by 5\% LSO supplementation to diets with high (75:25) and low (25:75) F:C ratios. When linseed was fed to lambs (6.7\% of DM; Machmüller et al., 2000), sheep (11\% of DM; Wachira et al., 2000), or lactating dairy cows (6.7\% 
of DM; Petit et al., 2002), however, total-tract digestibility was not affected.

With the forage-rich diets, the overall increase in total-tract $\mathrm{OM}, \mathrm{NDF}$, and ADF digestibility with LSO supplementation corresponded with an increase in ruminal digestibility of these fractions. However, with the concentrate-rich diet, there was an increase rather than a decrease in total-tract digestibility despite a decrease in ruminal fiber digestibility. Therefore, digestion in the large intestine compensated for the decrease in ruminal fiber digestion when the high-concentrate diet plus LSO was fed. Ikwuegbu and Sutton (1982) and Sutton et al. (1983) showed "compensatory" digestion of OM and fiber in the intestines when ruminal digestibility was decreased by LSO supplementation. Faichney et al. (2002) also showed that digestion in the large intestine partially compensated for the negative effect of unsaturated lipids on ruminal digestion. An interesting observation by Ikwuegbu and Sutton (1982) was that the compensation was complete at $2.2 \%$ LSO, but not at $6.6 \%$. In the present study, the compensation was complete with $\mathrm{CO}$, which contained $3 \%$ LSO.

Although ruminal starch digestibility was not affected $(P>0.05)$ by LSO supplementation (Table 2$)$, there was an interaction $(P<0.05)$ between $\mathrm{F}$ :C and LSO. Ruminal starch digestibility decreased with LSO supplementation to the forage-rich diet, whereas it increased with the concentrate-rich diet. The interaction found in the present study for ruminal starch digestibility did not agree with previous in vitro data obtained with rapeseed oil addition to a hay- or corn silage-based diet (Doreau et al., 1993). Starch digestion in the totaltract was nearly complete and was not affected $(P>$ $0.05)$ by LSO supplementation. Although there was an interaction $(P<0.05)$, the low SEM associated with total tract starch digestibility suggests that differences may not be biologically meaningful. Similar to results from the present study, no effect of LSO supplementation on total tract or ruminal digestibility of starch was observed in previous studies with sheep (Ikwuegbu and Sutton, 1982; McAllan et al., 1983).

\section{Microbial Activity}

In situ degradation kinetic parameters (a, b, c) of hay DM was not affected by $\mathrm{F}: \mathrm{C}$ ratio or LSO supplementation, except for an interaction $(P<0.10)$ and an effect of $\mathrm{F}: \mathrm{C}(P<0.05)$ for degradation rate of the slowly degradable fraction (c). These values were 2.09, 3.50, 1.80 , and $1.30 \% / \mathrm{h}$ for $\mathrm{F}, \mathrm{FO}, \mathrm{C}$, and $\mathrm{CO}$, respectively. There also was no effect of LSO on TD, indicating that LSO supplementation did not impair the ruminal microbial degradation of hay DM.
Since no interaction $(P>0.05)$ between time and treatments was detected for any measurement with ruminal fluid, only dietary effects are shown in Table 3. Ruminal fluid $\mathrm{pH}$ and total VFA concentration were not affected $(P>0.05)$ by F:C or LSO supplementation. These results were consistent with the absence of changes $(P>0.05)$ on ruminal OM digestibility by $\mathrm{F}: \mathrm{C}$ or LSO. Ikwuegbu and Sutton (1982) and Sutton et al. (1983) did not find changes in total ruminal VFA with LSO supplementation to sheep diets either, despite a marked decrease in ruminal carbohydrate fermentation. In contrast, Czerkawski et al. (1975) and Broudiscou et al. (1994), also working with sheep, reported decreases in total VFA concentration with LSO supplementation. Contradictory results among these studies may be due to differences in feeding patterns of animals or ruminal fluid sampling times.

A greater amount of concentrate in the diet decreased the proportion of acetate $(P<0.01)$ and iso-valerate $(P$ $<0.05)$, but increased propionate $(P<0.01), n$-valerate $(P<0.05)$, and caproate $(P<0.01)$ (Table 3$)$. Interactions between F:C and LSO supplementation were detected both for $i s o$ - and $n$-butyrate. Propionate and branchedchain VFA (iso-butyrate and iso-valerate) increased with LSO supplementation $(P<0.05)$, whereas $n$-butyrate decreased $(P<0.05)$. The increase in propionate and the decrease in $n$-butyrate with LSO supplementation are consistent with results from previous reports with sheep pertaining to LSO (Cottyn et al., 1971; Ikwuegbu and Sutton, 1982; Sutton et al., 1983) or linseed (Machmüller et al., 2000). A recent in vitro study confirmed that addition of LSO has the potential to increase propionate and decreased $n$-butyrate concentration (Jalc and Cerešnáková, 2001). In the present study, numerically lower acetate and higher propionate proportion was observed with $\mathrm{CO}$, probably reflecting lower ruminal fiber digestibility. Although the above studies did not report modifications in the proportions of branched-chain VFA (iso-butyrate and iso-valerate), in the present study, there were significant increases with LSO.

Only 4 genera of ruminal protozoa were detected (Table 3). There was an interaction between F:C and LSO supplementation for total protozoal numbers $(P<0.10)$ and Entodinium numbers $(P<0.10)$. This interaction was primarily due to a drastic decrease with $\mathrm{CO}$ (total protozoa: 15\% of control). The decrease in protozoal numbers with $\mathrm{CO}$ was consistent with previous studies with LSO or other unsaturated lipid supplements, with reductions varying between 0 and $74 \%$ (Doreau and Ferlay, 1995). The strong decrease in protozoal numbers with $\mathrm{CO}$ was associated with decreases in ruminal fiber digestibility and $n$-butyrate in ruminal fluid, as reported previously (Jouany and Ushida, 1999). Con- 
Table 3. Ruminal pH, VFA concentration and composition, and protozoa population in cows fed diets containing a high proportion of forage without (F) or with linseed oil (FO), and a high proportion of concentrate without (C) or with linseed oil (CO).

\begin{tabular}{|c|c|c|c|c|c|c|c|c|}
\hline \multirow[b]{2}{*}{ Variable } & \multicolumn{4}{|c|}{ Diet } & \multirow[b]{2}{*}{ SEM } & \multicolumn{3}{|c|}{ Effect $(P=)$} \\
\hline & $\mathrm{F}$ & FO & $\mathrm{C}$ & $\mathrm{CO}$ & & $\mathrm{F}: \mathrm{C}$ & Oil & Int $^{1}$ \\
\hline $\mathrm{pH}$ & 6.34 & 6.44 & 6.31 & 6.44 & 0.12 & 0.84 & 0.17 & 0.86 \\
\hline Total VFA, $\mathrm{m} M$ & 95.7 & 94.8 & 91.3 & 91.3 & 6.0 & 0.29 & 0.90 & 0.91 \\
\hline \multicolumn{9}{|c|}{ Individual VFA, mol/100 mol } \\
\hline Acetate & 66.0 & 65.8 & 61.1 & 59.8 & 1.4 & $<0.01$ & 0.20 & 0.35 \\
\hline Propionate & 20.1 & 20.7 & 22.0 & 24.7 & 1.0 & $<0.01$ & 0.04 & 0.16 \\
\hline iso-Butyrate & 0.9 & 1.0 & 0.8 & 1.1 & 0.04 & 0.08 & $<0.01$ & 0.02 \\
\hline$n$-Butyrate & 10.5 & 9.7 & 11.2 & 9.4 & 0.6 & 0.73 & 0.04 & $<0.01$ \\
\hline iso-Valerate & 1.3 & 1.5 & 1.0 & 1.3 & 0.1 & 0.03 & 0.02 & 0.51 \\
\hline$n$-Valerate & 1.1 & 1.2 & 3.2 & 3.2 & 0.6 & $<0.01$ & 0.81 & 0.86 \\
\hline Caproate & $<0.1$ & $<0.1$ & 0.6 & 0.5 & 0.1 & $<0.01$ & 0.38 & 0.66 \\
\hline \multicolumn{9}{|l|}{ Protozoa, $10^{3} / \mathrm{mL}$} \\
\hline Isotricha sp. & 2.2 & 2.1 & 1.4 & 1.2 & 0.6 & 0.13 & 0.75 & 0.90 \\
\hline Dasytricha sp. & 1.7 & 1.1 & 0.9 & 0.3 & 0.4 & 0.03 & 0.11 & 0.99 \\
\hline Entodinium sp. & 77.8 & 87.5 & 73.8 & 10.2 & 19.0 & 0.03 & 0.14 & 0.05 \\
\hline Epidinium sp. & 3.8 & 1.0 & 4.1 & 1.1 & 1.1 & 0.82 & $<0.01$ & 0.90 \\
\hline Total & 85.5 & 91.8 & 80.2 & 12.9 & 20.1 & 0.03 & 0.11 & 0.06 \\
\hline
\end{tabular}

${ }^{1}$ Int = interaction between $\mathrm{F}: \mathrm{C}$ and oil.

trary to results pertaining to LSO (Broudiscou et al., 1994), the number of Holotrichs (Isotricha and Dasytri$(\mathrm{ch} a$ ) was not decreased by LSO supplementation in the present study $(P>0.05)$. Dasytricha numbers were greater with the forage-rich vs. concentrate-rich diet $(P$ $<0.05$ ). Total protozoal numbers in this study were lower than those typically observed (Jouany and Ushida, 1999). In the present study, this may be a carryover effect of the precedent treatment, even though there was a 3 -wk adaptation period.

\section{Ruminal Nitrogen Metabolism}

Intake of $\mathrm{N}$ did not differ $(P>0.05)$ among treatments (Table 4). Ruminal ammonia $\mathrm{N}$ concentration was greater with the forage-rich than with the concentraterich diet $(P<0.01)$, and also was greater with LSO supplementation $(P<0.01)$. Results from previous reports concerning LSO or linseeds, however, are variable. In studies with sheep fed hay and concentrate (Ikwuegbu and Sutton, 1982; Broudiscou et al., 1994), a decrease in ruminal ammonia $\mathrm{N}$ was observed with LSO supplementation. In contrast, an increase in ruminal ammonia $\mathrm{N}$ was observed in steers fed grass silage and concentrate (Scollan et al., 2001) or in vitro (Jalc and Cerešnáková, 2001). In the present study, the greater ruminal ammonia $\mathrm{N}$ concentration when $\mathrm{FO}$ or $\mathrm{CO}$ were fed was not likely due to the proportion of dietary soybean meal. Diets were formulated according to INRA guidelines (1989), so that none of them contained an excess of ruminally degradable protein compared with the potential of use of degradable protein for microbial synthesis. Despite the response in ruminal ammonia $\mathrm{N}$ with LSO, ruminal bacterial $\mathrm{N}$ concentration of LAB and SAB was not affected $(P>0.05)$ by LSO. We took into account the difference in distribution and composition between $\mathrm{LAB}$ and $\mathrm{SAB}$ to determine duodenal microbial $\mathrm{OM}$ and $\mathrm{N}$ flow. However, when calculated by the reference method (i.e., using only $\mathrm{LAB}$ ), overall means for $\mathrm{OM}$ and $\mathrm{N}$ flows were very close (3588 vs. 3834 and $335 \mathrm{vs.} 347 \mathrm{~g} / \mathrm{d}$ for the reference method and the present method, respectively).

Nonammonia $\mathrm{N}$ flow to the duodenum was greater $(P<0.05)$ with concentrate-rich diets and was not affected $(P>0.05)$ by LSO supplementation, although there was an interaction between F:C and LSO $(P<$ 0.10 , Table 4). Bacterial $\mathrm{N}$ flow followed the same pattern in response to LSO and F:C. Duodenal flow of nonammonia $\mathrm{N}$ decreased with LSO supplementation to the forage-rich diet, but increased when fed with the concentrate-rich diet. This was due to an increase in bacterial $\mathrm{N}$ flow with $\mathrm{CO}$. A similar response was reported in previous studies with different unsaturated lipids fed to dairy cows, but also with LSO supplementation to sheep diets (Ikwuegbu and Sutton, 1982; Sutton et al., 1983; Broudiscou et al., 1994). This effect is typically seen when oils decrease ruminal protozoal numbers, as in the present study. Defaunation could increase duodenal bacterial $\mathrm{N}$ flow by decreasing protozoal predation of ruminal bacteria and competition for substrates between these microorganisms (Jouany and Ushida, 1999). However, feeding FO decreased bacterial $\mathrm{N}$ flow with no change in ruminal protozoa numbers.

Efficiency of bacterial $\mathrm{N}$ synthesis was not affected ( $P$ $>0.05$ ) by either F:C or LSO supplementation. However, 
Table 4. $\mathrm{N}$ intake and ruminal metabolism and digestion by cows fed diets containing a high proportion of forage without (F) or with linseed oil (FO), and a high proportion of concentrate without (C) or with linseed oil (CO).

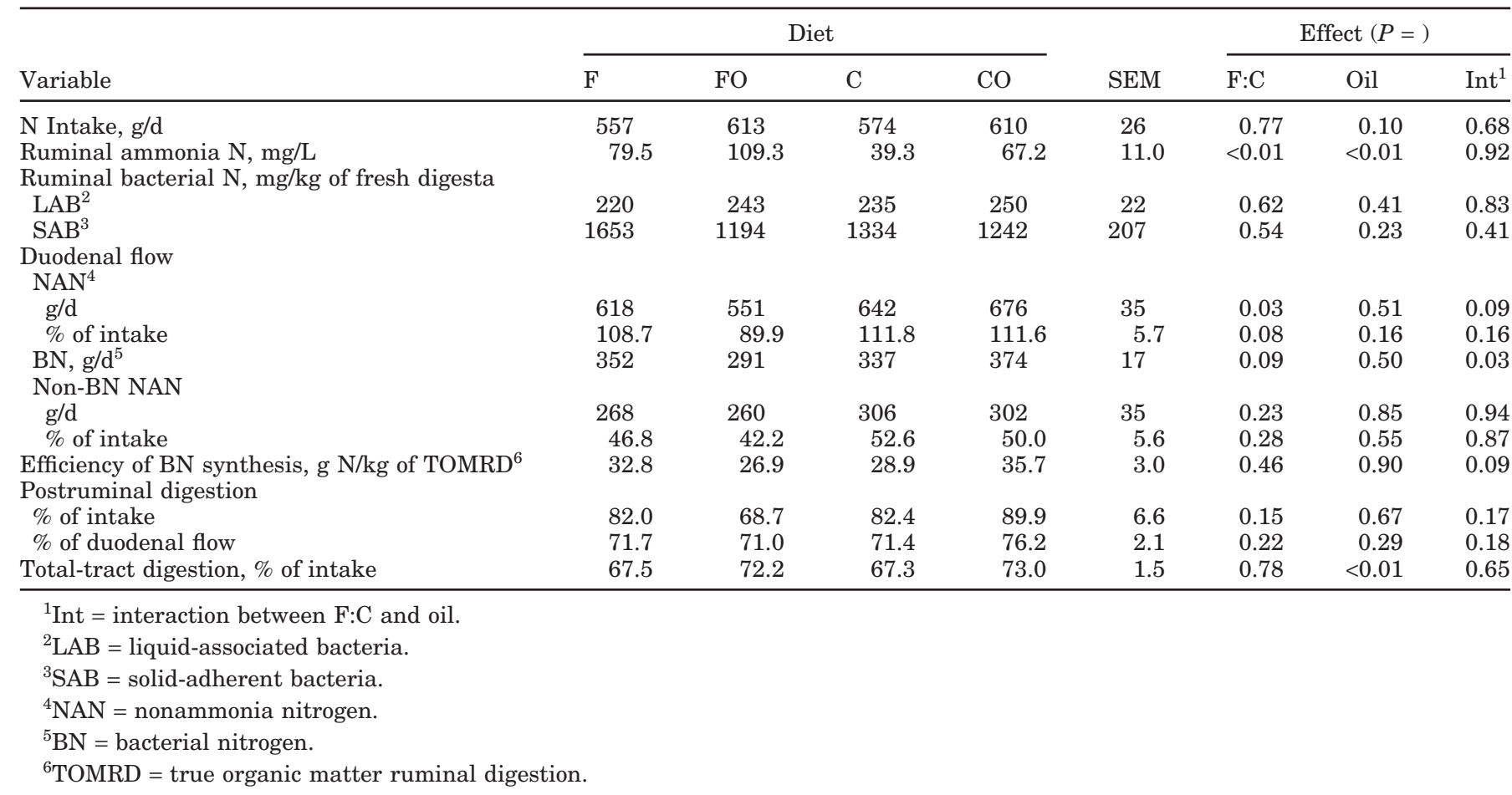

feeding CO resulted in greater efficiency of bacterial $\mathrm{N}$ synthesis and an interaction $(P<0.10)$ between $\mathrm{F}: \mathrm{C}$ and LSO supplementation (Table 4). This increase seemed primarily associated with a decrease in true ruminal $\mathrm{OM}$ digestibility when $\mathrm{CO}$ was fed because the increase in bacterial $\mathrm{N}$ flow in response to $\mathrm{CO}$ was relatively minor. Studies with sheep reported an increase in efficiency of bacterial $\mathrm{N}$ synthesis and a decrease in ruminal OM digestibility with LSO (Sutton et al., 1983; Broudiscou et al., 1994).

Apparent $\mathrm{N}$ digestibility in the total tract was greater $(P<0.01)$ with LSO-supplemented diets, whereas intestinal $\mathrm{N}$ digestion was not affected $(P>0.05)$ by $\mathrm{F}: \mathrm{C}$ or LSO supplementation (Table 4). In addition, duodenal flow of nonbacterial/nonammonia $\mathrm{N}$ was not affected $(P>0.05)$ by LSO supplementation suggesting LSO supplementation did not affect ruminal degradation of dietary N. Although the increase in apparent total-tract $\mathrm{N}$ digestibility with LSO supplementation was similar to the response observed for other chemical components, the causal factor was not clear.

\section{CONCLUSIONS}

Results from the present study question the widely spread idea, which arose from studies with sheep fed at maintenance with more than $5 \%$ LSO, that LSO decreases diet digestibility. Linseed oil supplementa- tion (3\% of diet DM) in dairy cows, regardless of dietary $\mathrm{F}: \mathrm{C}$, did not decrease total-tract digestibility of $\mathrm{OM}$, fiber, or N. It is unclear whether differences between literature data and the current study are associated with level of LSO supplementation or species differences in DMI (low intake in sheep vs. high intake in cows). Although LSO supplementation appeared to have a negative influence on ruminal fiber digestion when the diet contained a high level of concentrate, intestinal digestion compensated for this effect. Supplementation with LSO decreased ruminal protozoal numbers only with the concentrate-rich diet. This decrease may have led to greater duodenal bacterial $\mathrm{N}$ flow and efficiency of bacterial $\mathrm{N}$ synthesis, probably due to decreases in protozoal predation of ruminal bacteria or competition for substrates.

\section{ACKNOWLEDGMENTS}

The authors express their sincere appreciation to A. Ollier and all staff members of the Experimental FarmDairy Unit Les Cèdres for care and feeding of the cows. We especially thank D. Roux and F. Anglard, and appreciate the expertise of S. Gachon, B. Chauveau-Duriot, and E. Aurousseau in analyzing samples. This study was conducted as part of the "Healthy Beef" project supported financially by the EU. 


\section{REFERENCES}

Anonymous. 1988. Arrêté du 19 avril 1988 fixant les conditions d'attribution de l'autorisation d'expérimenter. Journal Officiel de la République Française, 27 avril 1988:5608-5610.

AOAC. 1990. Official Methods of Analysis. 14th ed. Assoc. Offic. Anal. Chem., Arlington, VA.

Bateman, II, H. G., and T. C. Jenkins. 1998. Influence of soybean oil in high fiber diets fed to nonlactating cows on ruminal unsaturated fatty acids and nutrient digestibility. J. Dairy Sci. 81:2451-2458.

Ben Salem, H., R. Krzeminski, A. Ferlay, and M. Doreau. 1993. Effect of lipid supply on in vivo digestion in cows: comparison of hayand corn-silage diets. Can. J. Anim. Sci. 73:547-557.

Broudiscou, L., S. Pochet, and C. Poncet. 1994. Effect of linseed oil supplementation on feed degradation and microbial synthesis in the rumen of ciliate-free and refaunated sheep. Anim. Feed Sci. Technol. 49:189-202.

Chilliard, Y., J. M. Chabosseau, J. Rouel, P. Capitan, C. Gominard, P. Gaborit, P. Juanéda, and A. Ferlay. 2002. Interactions between forage nature and sunflower or linseed oil supplementation on goat milk fatty acids of interest for human nutrition. Grassland Sci. Eur. 7:548-549.

Chilliard, Y., A. Ferlay, and M. Doreau. 2001. Effect of different types of forages, animal fat or marine oils in cow's diet on milk fat secretion and composition, especially conjugated linoleic acid (CLA) and polyunsaturated fatty acids. Livest. Prod. Sci. 70:31-48.

Cottyn, B., F. X. Buysse, and Ch. V. Boucqué. 1971. The effect of linseed oil fatty acids on digestibility and rumen function. $\mathrm{Z}$. Tierphysiol. Tierernaehr. Futtermittelkd. 27:252-259.

Czerkawski, J. W., W. W. Christie, G. Breckenridge, and M. L. Hunter. 1975. Changes in the rumen metabolism of sheep given increasing amounts of linseed oil in their diet. Br. J. Nutr. 34:25-44.

Demeyer, D., and M. Doreau. 1999. Targets and procedures for altering ruminant meat and milk lipids. Proc. Nutr. Soc. 58:593-607.

Dhiman, T. R., L. D. Satter, M. W. Pariza, M. P. Galli, K. Albright, and M. X. Tolosa. 2000. Conjugated linoleic acid (CLA) content of milk form cows offered diets rich in linoleic and linolenic acid. J. Dairy Sci. 83:1016-1027.

Doreau, M., H. Ben Salem, and R. Krzeminski. 1993. Effect of rapeseed oil on in vitro ruminal digestion in cows: comparison of hay and maize silage diets. Anim. Feed Sci. Technol. 44:181-189.

Doreau, M., and Y. Chilliard. 1997. Effects of ruminal or postruminal fish oil supplementation on intake and digestion in dairy cows. Reprod. Nutr. Dev. 37:113-124.

Doreau, M., and A. Ferlay. 1994. Digestion and utilization of fatty acids by ruminants. Anim. Feed Sci. Technol. 45:379-396.

Doreau, M., and A. Ferlay. 1995. Effect of dietary lipids on nitrogen metabolism in the rumen: A review. Livest. Prod. Sci. 43:97-110.

Doreau, M., F. Legay, and D. Bauchart. 1991. Effect of source and level of supplemental fat on total and ruminal organic matter and nitrogen digestion in dairy cows. J. Dairy Sci. 74:2233-2242.

Faichney, G.. J. 1980. The use of markers to measure digesta flow stomach in sheep fed once daily. J. Agric. Sci. (Camb.) 94:313-318.

Faichney, G.. J., G. L. R. Gordon, R. J. Welch, and A. J. Rintoul. 2002. Effect of dietary free lipid on anaerobic fungi and digestion in the rumen of sheep. Aust. J. Agric. Res. 53:519-527.

Faisant, N., V. Plachot, F. Kozlowski, M. P. Pacouret, P. Colonna, and M. Champ. 1995. Resistant starch determination adapted to products containing high level of resistant starch. Sci. Aliments 15:83-89.
Hussein, H. S., N. R. Merchen, and G. C. Fahey. 1995. Effects of forage level and canola seed supplementation on site and extent of digestion of organic matter, carbohydrate, and energy by steers. J. Anim. Sci. 73:2458-2468.

Ikwuegbu, O. A., and J. D. Sutton. 1982. The effect of varying the amount of linseed oil supplementation on rumen metabolism in sheep. Br. J. Nutr. 48:365-375.

INRA. 1989. Ruminant Nutrition. Recommended Allowances and Feed Tables. R. Jarrige, ed. Institut National de la Recherche Agronomique. John Libbey Eurotext, Paris, France.

Jalc, D., and Z. Cerešnáková. 2001. Effect of plant oils and aspartate on rumen fermentation in vitro. J. Anim. Physiol. Anim. Nutr. 85:378-384.

Jenkins, T. C. 1993. Lipid metabolism in the rumen. J. Dairy Sci. 76:3851-3863.

Jouany, J. P., and K. Ushida. 1999. The role of rumen protozoa in feed digestion. Asian-Aust. J. Anim. Sci. 12:113-128.

Lassalas, B., J. P. Jouany, and L. Broudiscou. 1993. Dosage des bases puriques et pyrimidiques par chromatographie liquide à haute performance. Ann. Zootech. 42:170-171.

Loor, J. J., A. Ferlay, A. Ollier, M. Doreau, and Y. Chilliard. 2002a. Conjugated linoleic acids (CLA), trans fatty acids, and lipid content in milk from Holstein cows fed a high- or low-fiber diet with two levels of linseed oil. J. Dairy Sci. 85(Suppl. 1):1188.

Loor, J. J., K. Ueda, A. Ferlay, Y. Chilliard, and M. Doreau. 2002b. Patterns of biohydrogenation and duodenal flow of trans fatty acids and conjugated linoleic acids (CLA) are altered by fiber level and linseed oil in dairy cows. J. Dairy Sci. 85(Suppl. 1):1255.

Machmüller, A., D. A. Ossowski, and M. Kreuzer. 2000. Comparative evaluation of the effects of coconut oil, oilseeds and crystalline fat on methane release, digestion and energy balance in lambs. Anim. Feed Sci. Technol. 85:41-60.

Malawer, S. J., and D. W. Powell. 1967. An improved turbidimetric analysis of polyethylene glycol utilizing and emulsifier. Gastroenterology 53:250-256.

McAllan, A. B., R. Knight, and J. D. Sutton. 1983. The effect of free and protected oils on the digestion of dietary carbohydrates between the mouth and duodenum of sheep. Br. J. Nutr. 49:433-440.

Palmquist, D. L. 1988. The feeding value of fats. Pages 293-311 in Feed Science. E. R. Ørskov, ed. Elsevier Sci. Publ. A. V., Amsterdam, Netherlands.

Petit, H. V., R. J. Dewhurst, N. D. Scollan, J. G. Proulx, M. Khalid, W. Haresign, H. Twagiramungu, and G. E. Mann. 2002. Milk production and composition, ovarian function, and prostaglandin secretion of dairy cows fed omega-3 fats. J. Dairy Sci. 85:889-899.

Roche, H. M., E. Noone, A. Nugent, and M. J. Gibney. 2001. Conjugated linoleic acid: A novel therapeutic nutrient? Nutr. Res. Rev. 14:173-187.

Scollan, N. D., M. S. Dhanoa, N. J. Choi, W. J. Maeng, M. Enser, and J. D. Wood. 2001. Biohydrogenation and digestion of long chain fatty acids in steers fed on different sources of lipids. J. Agric. Sci. (Camb.) 136:345-355.

Sutton, J. D., R. Knight, A. B. McAllan, and R. H. Smith. 1983. Digestion and synthesis in the rumen of sheep given diets supplemented with free and protected oils. Br. J. Nutr. 49:419-432.

Van Soest, P. J., J. B. Robertson, and B. A. Lewis. 1991. Methods for dietary fiber, neutral detergent fiber, and non-starch polysaccharides in relation to animal nutrition. J. Dairy Sci. 74:35383597.

Wachira, A. M., L. A. Sinclair, R. G. Wilkinson, K. Hallett, M. Enser, and J. D. Wood. 2000. Rumen biohydrogenation of $n-3$ polyunsaturated fatty acids and their effects on microbial efficiency and nutrient digestibility in sheep. J. Agric. Sci. (Camb.) 135:419-428. 